\title{
PERILAKU CARING PERAWAT DIMASA PANDEMI COVID-19 DI RUMAH SAKIT UMUM DAERAH KOTA MAKASSAR
}

\author{
Zaenal,Noer Saudah,Imam Zaenuri dan Rini Mustamin \\ Program Studi Magister Keperawatan Stikes STIKES Bina Sehat PPNI Mojokerto \\ Email: zaenalnurdinfikuim@gmail.com
}

\begin{abstract}
ABSTRAK
Tujuan penelitian: untuk mengetahui mengetahui gambaran perilaku caring perawat di ruang rawat Rumah Sakit Umum Daerah Kota Makassar. Metode: Penelitian ini menggunakan survey diskriptif dengan menggunakan teknik non probability sampling yaitu consecutive sampling. sampel dalam penilitian ini 77 Orang sesuai dengan kriteria inklusi dan kriteria eksklusi. Pengumpulan data menggunakan kuisioner Care Q (the Nurse Behavior Caring Study) berdasarkan pendapat Larson (1998, dalam Watson 2004).lembar kuesioner. Hasil: Hasil penelitian menunjukan bahwa Perilaku caring perawat di Rumah Sakit Umum Daerah kota Makassar secara umum Sebagian besar adalah baik sebanyak (79,2 \%)Perilaku caring perawat bedasarkan dimensi Sebagian besar baik dengan penjelasan sebagai berikud kesiapan dan kesedian (77,9\%),penjelasan dan fasilitas $(79,9 \%)$, Kenyamanan(79,9 \%),hubungan saling percaya(71,4 \%). Diskusi: Dalam penerapan Perilaku caring perawat perlu mengintegrasikan berbagai dimensi perilaku caring yang meliputi kesiapan dan kesedian, penjelasan dan fasilitas, Kenyamanan,hubungan saling percaya untuk meningkatkan mutu pelayanan keperawatan yang berdampak pada peningkatan kepuasan pasien dan penurunan hari rawat. Simpulan: Perilaku caring perawat di Rumah Sakit Umum Daerah kota Makassar secara umum Sebagian besar adalah baik Saran: Diharapkan perawat membudayakan pelaksanaan caring perawat terhadap pasien dengan saling mengingatkan diantara teman sejawat untuk peningkatan mutu pelayanan keperawatan.
\end{abstract}

Kata kunci : Perilaku, caring

\begin{abstract}
The purpose of the study: to find out the description of the caring behavior of nurses in the ward of the Makassar City General Hospital. Methods: This study used a descriptive survey using a nonprobability sampling technique, namely consecutive sampling. The sample in this study was 77 people according to the inclusion criteria and exclusion criteria. Collecting data using a questionnaire Care Q (the Nurse Behavior Caring Study) based on the opinion of Larson (1998, in Watson 2004). Questionnaire sheet. Results: The results showed that the caring behavior of nurses at the Makassar City General Hospital in general was mostly good (79.2\%). , explanation and facilities (79.9\%), comfort (79.9 \%), trusting relationship (71.4\%). Discussion: In the application of caring behavior nurses need to integrate various dimensions of caring behavior which include readiness and willingness, explanations and facilities, comfort, mutual trust relationships to improve the quality of nursing services which have an impact on increasing patient satisfaction and decreasing hospital days. Conclusion: Nurse caring behavior in Makassar City General Hospital in general is mostly good Suggestion: Nurses are expected to cultivate a culture of caring for patients by reminding each other among colleagues to improve the quality of nursing services.
\end{abstract}

Keywords: Behavior, caring

\section{PENDAHULUAN}

Pelayanan dibidang kesehatan tidak dapat dipisahkan dari institusi Rumah Sakit yang mempunyai budaya organisasi dan berperan utama mempercepat peningkatan derajat kesehatan optimal, yang tergambar dalam visi dan misi yang akan dicapai. Tujuan pelayanan kesehatan di rumah sakit yakni memberikan pelayanan sesuai dengan standar pelayanan dan bermutu. Perilaku kinerja perawat sebagai salah satu tim kerja pemberi pelayanan adalah hal yang paling esensi dalam penentuan kualitas layanan (Pohan, 2007).

Caring adalah hal yang pailing esensial dalam praktik keperawatan karena caring merupakan sebuah pendekatan dinamis yang sangat terkai dengan professionalisme perawat dalam bekerja supaya lebih perhatian dan bertanggung jawab kepada kliennya. Gibson, et.al (2006)

Kurangnya caring perawat dalam pelayanan keperawatan dapat berakibat 
penurunan mutu pelayanan keperawatan yang berdampak pada penurunan kepuasan pasien dan peningkatan hari rawat (Wolf \& Miller, 2003)

Di Indonesia caring menjadi salah satu penilaian bagi para pengguna pelayanan kesehatan. berdasarkan hasil survey kepuasan klien pada beberapa rumah sakit di Jakarta menunjukkan bahwa $14 \%$ klien tidak puas terhadap pelayanan kesehatan yang diberikan, disebabkan oleh perilaku caring perawat kurang baik (Kemenkes RI, dalam.(Firmansyah et al., 2019).

Noyumala (2013) melakukan penelitian tentang hubungan Antara Komponen Komitmen Perawat (Affectif, Normatif dan Continuance) dengan pelaksanaan patient safety, dari 3 komponen komitmen perawat ternyata hanya komponen komitmen normatif yang memiliki hubungan yang bermakna secara signifikan dengan pelaksanaan patient safety. Gambaran Perilaku Caring Profesional Perawat di RSUD Daya Kota Makassar sebagian besar perawat cenderung memiliki perilaku caring yang tinggi yaitu $54,7 \%$ atau sebanyak 41 orang sedangkan yang rendah $45,3 \%$ atau sebanyak 34 orang

Rumah Sakit Umum Daerah Daya merupakan rumah sakit milik pemerintah Kota Makassar dengan tipe B) memiliki kapasitas tempat tidur berjumlah 175 tempat tidur. Berdasarkan Survey Kepuasan Masyarakat (SKM) tri wulan pertama (Januari-Maret 2019) RSUD Kota Makassar ditemukan masalah terdapat sebagian kecil petugas yang kurang ramah dalam memberikan pelayanan di rumah sakit Umum Daerah Daya. Data Bed Occupation Rate /BOR) Angka penggunaan tempat tidur RSUD Daya pada tahun 2018 jumlah 24,68\%, Tahun 2019 jumlah $57,69 \%$ dan Tahun 2020 jumlah $29,40 \%$, Jumlah tenaga perawat ruang rawat inap di RSUD Daya Kota Makassar sebanyak 95 orang dengan perincian sebagai berikud Perawatan Interna /Amarilis :20 orang,Perawatan Bedah/ Gardenia:16 orang, Perawatan Isolasi /Mawar :16 Orang, Perawatan Anak/Tulip: 17 orang , perawatan Covid :26 orang, ICU : 15 orang (Data medical record bagian coding diagnose RSUD Daya Kota Makassar, 2021). Berdasarkan penelitian yang dilakukan oleh Dahlan et al., (2016) didapatkan distribusi tingkat kepuasan pasien $\mathrm{Di}$ ruang interna RSUD Daya Makassar yaitu yang puas 28 orang $(56 \%)$ dan yang tidak puas 7 orang $(14 \%)$ kemudian berdasarkan analisis bivariat didapatkan Ada pengaruh antara kepuasan pasien terhadap pelayanan kesehatan dari segi komunikasi, fasilitas pelayanan dan biaya perawat di ruang interna Rumah Sakit Umum Daerah Daya Makassar.

Penelitian Alim et al., (2019) mengidentifikasi kepuasan pasien rawat Jalan RSUD Makassar yang tidak puas sebanyak 64 $(34,4 \%)$ orang, dan yang puas sebanyak 122 $(65,6 \%)$ orang menunjukkan bahwa ada hubungan kehandalan terhadap kepuasan pasien rawat jalan $(p=0,002)$, ada hubungan jaminan terhadap kepuasan pasien rawat jalan $(p=0,000)$, ada hubungan bukti fisik terhadap kepuasan pasien rawat jalan $(p=0,000)$, tidak ada hubungan antara sikap ramah terhadap kepuasan pasien rawat jalan $(p=0,353)$, ada hubungan daya tanggap terhadap kepuasan pasien rawat jalan $(p=0,001)$

Berdasarkan latar belakang terebut peneliti tertarik untuk melakukan penelitian guna memperoleh informasi yang jelas tentang "Bagaimana Gambaran Perilaku Caring Perawat di Rumah Sakit Umum Daerah Kota Makassar."

\section{METODE}

Metode penelitian ini adalah metode survey diskriptif. Metode survey diskriptif didefinisikan sebagai suatu penelitian yang dilakukan untuk mendiskripsikan atau menggambarkan suatu fenomena yang terjadi dimasyarakat, memotret masalah kesehatan yang terkait dengan sekelompok penduduk (Notoatmodjo, 2010). Metode ini digunakan karena peneliti ingin mengetahui sejauh mana gambaran perilaku caring perawat di ruang rawat RSUD Kota Makassar tahun 2021

Penelitian ini dilaksanakan di Instalasi Rawat Inap RSUD Kota Makassar yang meliputi Perawatan Interna, Perawatan Bedah dan Perawatan Anak Perawatan Covid dan Pearwatan Isolasi pengambilan data dilakukan pada bulan Mei sampai Juni 2021.

Teknik pengambilan sampel yang digunakan adalah non probability sampling yaitu consecutive sampling artinya sampel yang diambil adalah seluruh subjek yang diamati dan memenuhi kriteria pemilihan sampel yang kemudian dimasukkan dalam sampel sampai besar sampel yang diperlukan terpenuhi (Sastroasmoro dan Ismael, 2008). Sampel diambil dengan cara memasukkan seluruh populasi yang memenuhi kriteria inklusi dan mengeluarkan sampel yang termasuk kriteria eksklusi. Seluruh sampel yang memenuhi kriteria diambil datanya dalam kurun waktu penelitian hingga besar sampel yang diinginkan terpenuhi. Analisis data dalam penelitian ini adalah analisis univariat yang bertujuan untuk menjelaskan atau mendiskripsikan karakteristik setiap variabel 
penelitian. Analisa univariat dilakukan untuk melihat distribusi frekuensi dan persentase dari perilaku caring perawat terhadap pasien. Analisis univariat merupakan analisis data yang dilakukan pada satu variabel dari penelitian(Notoadmodjo, 2012)..

\section{HASIL}

Tabel 5.1 menunjukkan dari 77 responden perawat dengan umur 26-45 tahun yaitu $92,2 \%$. Jenis kelamin sebagian besar adalah perempuan yakni $61,4 \%$. Tingkat pendidikan sebagian besar berpendidikan S1 Keperawatan 58,4\%, dan 59,6\% sudah kawin atau berstatus berkeluarga.

Lama bekerja sebagian besar atas 5 (lima) tahun yakni sebanyak $89,6 \%$, dan lama Tabel 5.1 : Karakateristik Responden kerja sebagai perawat paling banyak di atas 5 (lima) tahun yakni sebanyak $58,4 \%$ namun jumlah ini tidak berbeda jauh dengan jumlah perawat yang bekerja di ruang perawatan kurang dari 5 (lima) tahun yakni sebanyak 41,6\%. Berdasarkan status kepegawaian yang paling banyak yang non ASN sebanyak $62,3 \%$ dan yang ASN sebanyak 37,7\% .

Perilaku caring perawat di instalasi Rawat inap RSUD Kota Makassar diukur menurut persepsi perawat yang terdiri atas 2 kategori yaitu baik dan kurang. Hasil pengumpulan data mengenai caring perawat dapat dilihat table 5.2

Tabel 5.2 tersebut menunjukkan bahwa, rata - rata $(79,2)$ perawat perilaku caring dengan kategori baik dan $(20,8 \%)$ perilaku caring kurang.

\begin{tabular}{|c|c|c|c|}
\hline \multirow{2}{*}{ No. } & \multirow{2}{*}{ Karakteristk Responden } & \multicolumn{2}{|c|}{ Jumlah } \\
\hline & & $\mathrm{n}$ & $\%$ \\
\hline \multirow{5}{*}{1} & Usia & & \\
\hline & $<25$ tahun & 3 & 3,9 \\
\hline & $26-45$ tahun & 71 & 92,2 \\
\hline & $>45$ tahun & 3 & 3,9 \\
\hline & Jumlah & 77 & 100,0 \\
\hline \multirow{4}{*}{2} & Jenis Kelamin & & \\
\hline & Perempuan & 72 & 93,5 \\
\hline & Laki-laki & 5 & 6,5 \\
\hline & Jumlah & 77 & 100,0 \\
\hline \multirow{4}{*}{3} & Pendidikan & & \\
\hline & Diploma (III) & 32 & 41,6 \\
\hline & S1 Keperawatan & 45 & 58,4 \\
\hline & Jumlah & 77 & 100,0 \\
\hline \multirow{4}{*}{4} & Status Perkawinan & & \\
\hline & Kawin & 34 & 59,6 \\
\hline & Belum kawin & 23 & 40,4 \\
\hline & Jumlah & 57 & 100,0 \\
\hline \multirow{4}{*}{5} & Lama kerja di Ruang Perawatan & & \\
\hline & $\leq 5$ tahun & 8 & 10,4 \\
\hline & $>5$ tahun & 69 & 89,6 \\
\hline & Jumlah & 77 & 100,0 \\
\hline \multirow{4}{*}{6} & Lama kerja Sebagai Perawat & & \\
\hline & $\leq 5$ tahun & 32 & 41,6 \\
\hline & $>5$ tahun & 45 & 58,4 \\
\hline & Jumlah & 77 & 100,0 \\
\hline \multirow{4}{*}{8} & Status Kepegawaian & & \\
\hline & Non PNS & 48 & 79,2 \\
\hline & PNS & 29 & 20,8 \\
\hline & Jumlah & 77 & 100,0 \\
\hline
\end{tabular}


Tabel 5.2 : Distribusi Frekkuensi Perilaku Caring Perawat di instalasi Rawat inap di RSUD Kota Makassar,

\begin{tabular}{|c|c|c|c|c|c|c|c|}
\hline \multirow{3}{*}{ No. } & \multirow{3}{*}{ Perilaku Caring } & \multicolumn{4}{|c|}{ Jawaban Responden } & \multicolumn{2}{|c|}{ Total } \\
\hline & & \multicolumn{2}{|c|}{ Baik } & \multicolumn{2}{|c|}{ Kurang } & \multirow[t]{2}{*}{$\mathrm{n}$} & \multirow[t]{2}{*}{$\%$} \\
\hline & & $\mathrm{n}$ & $\%$ & $\mathrm{n}$ & $\%$ & & \\
\hline 1 & Kesiapan \& kesediaan & 60 & 77,9 & 17 & 22,1 & 77 & 100 \\
\hline 2 & Penjelasan \& Fasilitas & 61 & 79,2 & 16 & 20,8 & 77 & 100 \\
\hline 3 & Kenyamanan & 73 & 94,8 & 4 & 5,2 & 77 & 100 \\
\hline 4 & Hubungan saling percaya & 55 & 71,4 & 22 & 28,6 & 77 & 100 \\
\hline 5 & Tindakan Antisipasi & 56 & 72,7 & 21 & 27,3 & 77 & 100 \\
\hline 6 & Monitoring dan follow up kesehatan pasien & 56 & 72,7 & 21 & 27,3 & 77 & 100 \\
\hline
\end{tabular}

Jumlah rata-rata

Sumber : hasil olahan data pimer, 2021

Tabel 5.3 : Distribusi Frekkuensi Perilaku Caring Perawat di instalasi Rawat inap di RSUD Kota Makassar,

\begin{tabular}{llll}
\hline & & $\mathrm{n}$ & $\%$ \\
\hline 1 & Perilaku Caring & & \\
\hline 2 & Kurang & 61 & 79,2 \\
\hline & Total & 16 & 20,8 \\
\hline
\end{tabular}

Sumber : hasil olahan data pimer, 2021

\section{DISKUSI}

A. Perilaku Caring Perawat

Hasil penelitian tentang perilaku caring perawat pada 77 perawat Rumah Sakit Umum Daerah kota Makassar didapatkan perilaku caring perawat keseluruhan adalah Baik, yaitu sebanyak 61 perawat $(79,2 \%)$ sedangkan kategori kurang terdapat 16 perawat $(20,8 \%)$. Dari hasil penelitian tersebut disimpulkan bahwa gambaran perilaku caring perawat di Rumah Sakit Umum Daerah kota Makassar berada pada kategori baik. Hasil penelitian ini sejalan dengan penelitian yang dilaksanakan oleh Martauli (2014) tentang perilaku caring perawat di rumah sakit "T" Jakarta, penelitian ini dilaksanakan di dua ruang berbeda yaitu di ruangan rawat inap bedah didapatkan hasil bahwa $80 \%$ perawat yang berada di ruang tersebut telah melaksanakan perilaku caring dengan sangat baik. Ruang lainnya dalam penelitian tersebut yaitu ruang rawat inap penyakit dalam dengan hasil $76 \%$ perawat telah melaksanakan perilaku caring dengan sangat baik. Peneliti menyimpulkan bahwa perilaku caring perawat di Rumah Sakit Prince Nayef bin Abdul Aziz Universitas Syiah Kuala secara keseluruhan sudah baik dikarenakan perawat sadar bahwa perilaku caring adalah hal utama dalam asuhan keperawatan yang harus dimiliki oleh setiap perawat. Hal ini sesuai dengan yang dikemukakan Muzaiyanah Ridha dan Mayasari Putri (2019) terkait dengan caring perawat yang sangat penting dan berpengaruh dalam meningkatkan kepuasan pasien, memperbaiki kondisi lingkungan kerja.

B. Perilaku caring perawat ditinjau dari Kesiapan \& Kesedian

Hasil penelitian tentang perilaku caring perawat ditinjau dari Kesiapan \& Kesedian pada 77 perawat Rumah Sakit Umum Daerah kota Makassar didapatkan hasil bahwa perilaku caring perawat dalam Kesiapan \& Kesedian secara keseluruhan adalah baik, yaitu sebanyak 60 perawat $(77,9 \%)$. Hal ini sejalan dengan penelitian Desianora dkk., (2019) tentang Kesiapan dan kesediaan dari perawat bertujuan untuk menjadikan hubungan perawat dan klien yang saling terbuka, menghargai perasaan dan memberikan pengalaman antara perawat, klien, dan keluarga. Manifestasi perilaku yang dilakukan perawat antara lain perawat memberi kesempatan kepada klien untuk mengekspresikan perasaaan, perawat menyatakan penerimaannya terhadap klien, mengungkapkan kesediaannya untuk membantu klien dalam mengatasi permasalahan klien, memberikan dorongan kepada klien untuk mengungkapkan harapannya dan menjadi pedengar yang aktif bagi klien

Peneliti berpendapat bahwa pelaksanaan tindakan keperawatan, perilaku caring perawat dimensi mengakui keberadaan manusia masih perlu adanya peningkatan, hal ini dikarenakan hal ini dikarenakan masih terdapat beberapa perawat yang berada pada kategori rendah. Mengakui keberadaan 
manusia merupakan salah satu bagian dari perilaku caring yang jika dijalankan dengan baik maka dapat menggali keluhan-keluhan dari penyakit pasien serta akan dapat meningkatkan kepercayaan pasien. Hal tersebut akan membantu tindakan keperawatan maupun tindakan medis lainnya sehingga mempercepat proses penyembuhan pasien dan mampu memberikan rasa aman pada pasien.

\section{Perilaku caring perawat ditinjau dari penjelasan \& Fasilitas}

Hasil penelitian tentang perilaku caring perawat ditinjau dari penjelasan \& Fasilitas pada 77 perawat Rumah Sakit Umum Daerah kota Makassar didapatkan hasil bahwa perilaku caring perawat dalam penjelasan \& Fasilitas secara keseluruhan adalah baik, yaitu sebanyak 60 perawat $(79,9 \%)$. Penyelesaian masalah dalam memberikan asuhan keperawatan dapat menggunakan pendekatan keperawatan berdasarkan dengan penjelasan dan fasilitasi. Penjelasan dan fasilitasi adalah kemampuan yang dimiliki perawat dalam menyampaikan penjelasan yang berkenaan dengan perawatan klien, pengambilan keputusan, dan pendidikan kesehatan untuk klien dan keluarganya. Menurut Desianora dkk. (2019) manifestasi perilaku caring perawat yaitu perawat bertanggung jawab untuk membangun lingkungan yang mendukung dalam memberikan pendidikan kesehatan yang sebanding dengan kebutuhan klien, menyakinkan klien tentang kesediaan perawat dalam memberikan informasi, dan membantu klien dalam memberikan keputusan dalam memecahkan permasalahan secara keilmuan dalam menjalankan pelayanan yang berpusat kepada klien, serta menjaga klien dari praktik yang merugikan dan menjadi mediator antara klien dengan anggota kesehatan lainnya.

\section{Perilaku caring perawat ditinjau dari} Kenyamanan

Hasil penelitian tentang perilaku caring perawat ditinjau dari Kenyamanan pada 77 perawat Rumah Sakit Umum Daerah kota Makassar didapatkan hasil bahwa perilaku caring perawat dalam Kenyamanan secara keseluruhan adalah baik, yaitu sebanyak 60 perawat $(79,9 \%)$. Kebutuhan dasar klien dilakukan perawat dengan memperhatikan kenyamanan klien. Seorang perawat harus memiliki kemampuan kenyamanan

dalam mencukupi kebutuhan dasar klien yakni fisik, emosional dan penghargaan. Menurut Desianora dkk., (2019) manifestasi perilaku caring perawat antara lain membatu dengan tulus kebutuhan Activity Daily Living (ADL), menghargai dan menghormati privasi klien, dan memperlihatkan rasa menghormati dan menghargai kepada klien.

E. Perilaku caring perawat ditinjau dari hubungan saling percaya

Hasil penelitian tentang perilaku caring perawat ditinjau dari hubungan saling percaya pada 77 perawat Rumah Sakit Umum Daerah kota Makassar didapatkan hasil bahwa perilaku caring perawat dalam hubungan saling percaya secara keseluruhan adalah baik, yaitu sebanyak 55 perawat $(71,4 \%)$. Perilaku caring perawat harus menggambarkan trusting relatioship yakni kemampuan perawat dalam membina hubungan interpersonal dengan klien, memperlihatkan rasa tanggung jawab kepada klien dan selalu menafsirkan klien sesuai kondisinya. Manifestasi perilaku caring perawat antara lain hadir secara fisik dan jujur, memiliki kemampuan untuk merasakan dan memahami perasaan klien, dan berbicara dengan klien menggunakan suara yang sedang dan sikap tenang (Desianora dkk., 2019). Perawat dalam membina hubungan interpersonal dengan klien harus memberikan informasi dengan jujur, dan memperlihatkan sikap empati. Sikap ini merupakan

hubungan saling menguntungkan dan sangat penting bagi terbentuknya

transcultural caring. Transcultural caring merupakan sikap antara perawat dan

klien yang dapat meningkatkan penerimaan, perwujudan perasaan positif dan

negatif (Clark, 2003). Pendapat ini didukung oleh Potter \& Perry (2009)

mengemukan hubungan saling percaya diawali dengan belajar membangun dan mendukung pertolongan-kepercayaan, hubungan caring, melalui komunikasi yang efektif dengan klien.

F. Perilaku caring perawat ditinjau dari Tindakan Antisepti

Hasil penelitian tentang perilaku caring perawat ditinjau dari Antisepti pada 77 perawat Rumah Sakit Umum Daerah kota Makassar didapatkan hasil bahwa perilaku caring perawat dalam Antisepti secara keseluruhan adalah baik, yaitu sebanyak 56 perawat $(72,7 \%)$. Perawat harus memiliki sikap anticipates dalam perilaku caring. Pelaksanaan caring dalam dimensi ini adalah melakukan pencegahan dan mengantisipasi perubahan-perubahan yang tidak dinginkan dari kondisi klien. Perawat dapat menyiapkan sesuatu yang dibutuhkan bila hal itu terjadi 
(Larson 1994, dalamWatson 2004).Perawat harus dapat belajar menghargai kesensitifitasan perasaan klien dan dirinya sendiri. Sensitif terhadap diri sendiri akan menjadikan lebih sensitif terhadap orang lain dan menjadi lebih tulus dalam memberikan bantuan kepada orang lain, lebih empati dalam proses interpersonal perawat dan klien (Clark, 2003).Manifestasi perilaku caring perawat: sikap empati, tenang dan sabar, menemani dan mendampingi klien, menempatkan dalam posisi klien, ikut merasakan dan prihatin terhadap ungkapan penderitaan yang di ungkapkan oleh klien, memahamiperilaku klien baik perilaku positif dan negatif dengan mengidentifikasikebutuhan psikologis klien. Gangguan biologis dapat disebabkan oleh adanyaganguan psikologis dan biologis itu sendiri (Stuart \& Laraia, 2005).

G. Perilaku caring perawat ditinjau dari monitoring dan follow up Kesehatan pasien

Hasil penelitian tentang perilaku caring perawat ditinjau dari monitoring dan follow up Kesehatan pasien pada 77 perawat Rumah Sakit Umum Daerah kota Makassar didapatkan hasil bahwa perilaku caring perawat dalam monitoring dan follow up Kesehatan pasien secara keseluruhan adalah baik, yaitu sebanyak 56 perawat $(72,7 \%)$. Pengenalan pengaruh lingkungan non fisik dan fisik perawat harus menjamin kemampuan profesionalnya dan keamanan tindakan keperawatan dalam membimbing dan mengawasi klien. Perilaku ini menurut Larson (1994 dalam Watson, 2004) adalah monitors dan follows. Perawat membuat pemulihan suasana pada semua tingkatan fisik maupun non fisik yang bersifat suportif, protektif, dan korektif. Perawat juga perlu mengenali pengaruh lingkungan internal dan eksternal klien terhadap kesehatan/kondisi penyakit klien.Manifestasi perilaku caring perawat: meningkatkan kebersamaan, keindahan,kenyamanan, kepercayaaan dan kedamaian dengan cara; menyetujui keinginanklien untuk bertemu dengan pemuka agama dan menghadiri pertemuannya,bersedia mencarikan alamat dan atau menghubungi keluarga yang ingin ditemui

oleh klien. Menyediakan tempat tidur yang selalu rapih dan bersih, menjagakebersihan dan ketertiban ruang perawatan, melakukan kunjungan rumah saat klien pulang (Stuart \& Laraia, 2005).

\section{SIMPULAN}

Berdasarkan penelitian diatas dapat disimpulkan:

1. Perilaku caring perawat di Rumah Sakit Umum Daerah kota Makassar secara umum Sebagian besar adalah Baik sebanyak $(79,2$ $\%)$

2. Perilaku caring perawat dalam Kesiapan \& Kesedian secara keseluruhan adalah baik, yaitu sebanyak $(77,9 \%)$.

3. Perilaku caring perawat dalam penjelasan \& Fasilitas secara keseluruhan adalah baik, yaitu sebanyak $(79,9 \%)$.

4. Perilaku caring perawat dalam Kenyamanan secara keseluruhan adalah baik, yaitu sebanyak $(79,9 \%)$.

5. Perilaku caring perawat dalam hubungan saling percaya secara keseluruhan adalah baik, yaitu sebanyak $(71,4 \%)$.

\section{SARAN}

1. Bagi tenaga perawat/bidan

Membudayakan pelaksanaan caring perawat terhadap pasien dengan saling mengingatkan diantara teman sejawat untuk peningkatan mutu pelayanan keperawatan.

2. Bagi RS bhayangkara makassar

Perlu dukungan dan kebijakan rumah sakit berupa sistem reward bagi ruangan yang perawatnya melakukankan caring dengan pasien

3. Bagi Peneliti

Penelitian selanjutnya dapat dilakukan dengan menggunakan metode yang berbeda seperti pre eksperimen dan mengembangkan variabel- variabel yang belum diteliti pada penelitian ini sehingga dapat diketahui faktor-faktor lain yang dapat mempengaruhi perilaku caring perawat.

\section{REFERENSI}

Alim, A., Tangdilambi, N., \& Badwi, A. (2019). Stuart, G.Wail. (2016). Prinsip Dan Praktek Keperawatan Kesehatan Jiwa Edisi Indonesia. Elsevier Singapore.Jurnal Kualitas Pelayanan Kesehatan (Studi Analitik Terhadap Pasien Rawat Jalan di RSUD Makassar). Jurnal Manajemen Kesehatan Yayasan RS.Dr. Soetomo, 5(2), 165. https://doi.org/10.29241/jmk.v5i2.164

Clark, M. J. 2003. Community health nursing: caring for populations. New Jersey: Prentice Hall 2003.

Desianora. (2019). Faktor-Faktor Budaya Organisasi Yang Berhubungan Dengan Perilaku Caring Perawat Di Ruang Rawat Inap Rumah Sakit Umum Daerah Petala Bumi Provinsi Riau. XIII(2), 102-114.

Firmansyah, C. S., Noprianty, R., \& Karana, I. (2019). Perilaku Caring Perawat 
Berdasarkan Teori Jean Watson di Ruang Rawat Inap. Jurnal Kesehatan Vokasional, 4(1), https://doi.org/10.22146/jkesvo.40957

Gibson et al. (2008). Manajemen Sumber Daya Manusia. Jakarta : Erlangga.

Muzaiyanah Ridha dan Mayasari Putri (2019) Gambaran Perilaku Caring Perawat Di Rumah Sakit Di Banda Aceh JIM FKep Volume IV No. 2 Tahun 2019

Notoatmodjo, S. 2010. Metodologi Penelitian Kesehatan. Jakarta : Rineka Cipta.

2021

Noyumala1, Ariyanti. Saleh2, B. B. (n.d.). Profesional Melalui Pelaksanaan Patient Safety Di Rumah Sakit Umum Daerah Kota Makassar Nurse Commitment Relationship With The Professional Caring Behaviors Through Implementation Of Patient Safety In The General Hospital Of Makassar City 2fakultas Kedokteran

Larson. (2002). Religious Commitment and Health. APA. http : //www.tawakal.or.id.

Pohan, Imbalo. (2007). Jaminan Mutu Layanan Kesehatan : dasar-Dasar Pengertian Dan Penerapan. Jakarta : EGC

Potter PA \& Perry AG. 2005. Buku Ajar Fundamental Keperawatan Konsep, Proses dan Praktik Edisi 4, Jakarta: EGC.

Potter \& Perry. 2009. Fundamental Keperawatan. Edisi 7. Jakarta : Salem

Sastroasmoro, S. dan Ismail, S. 2008. DasarDasar Metodologi Penelitian Klinis Edisi III. Jakarta: CV Agung Seto

Wolf, Z.R,Miller,P.A, Devine,M. (2003). Relationship nurse caring and patient satisfaction in patient undergoing invasive cardiac procedures. Jornal of advanced nursing. Diakses di www.ncbi.nlm.nih.gov/pubmed/14725151 pada tanggal 10 April 202

Watson, J. 2007. Theory of Human Caring, Danish Clinical Nursing Journal.Available from www.uchsc.edu/nursing/caring. Diakses pada tanggal 5 Mei 2021. 